\title{
PROTECTIVE ACTIVITY OF SWEET SORGHUM AND SUGARCANE SYRUPS AGAINST OXIDATIVE STRESS INDUCED BY CADMIUM IN ALBINO RATS
}

Yara I.H. El-Geddawy ${ }^{1}$, Yousif ${ }^{2}$ E.I., Nessrien M.N.Yasin ${ }^{2}$ and Besheit ${ }^{1}$ S.Y.

1- Sugar Technology Dept., Sugar Crops Research Institute, Agric. Research Center, Giza, Egypt

2- Food Sci. Dept., Fac. of Agric., Ain Shams Univ., P.O. Box 68, Hadayek Shoubra 11241, Cairo, Egypt

*Corresponding author: yara_elgeddawy@yahoo.com

Received 16 May, 2019

Accepted 12 June, 2019

\section{ABSTRACT}

The present study was designed to investigate the effect of sweet sorghum and sugarcane syrups as antioxidants on oxidative stress biomarkers and the lipid profile i.e. serum total triglyceride (TG), total cholesterol (TC), high density lipoprotein cholesterol (HDL-C) and low density lipoproteins cholesterol (LDL-C)) in male rats. Cadmium was received orally to rats daily at a dose of $10 \mathrm{mg} / \mathrm{L}$ in drinking water. Rats were divided into four groups,eight rats for each- as follow: (I) control group, (II) cadmium treated group, (III) sweet sorghum syrup solution (500 ppm) once daily at a dose of $1 \mathrm{ml} / \mathrm{kg}$ body weight of cadmium acetate solution, (IV) sugarcane syrup solution (500 ppm) and cadmium acetate solution. Bioactive compounds of syrups under investigation were identified, total phenolic and flavonoid contents were determined as well. Results cleared that the effect of variation in varieties on total phenol (mg GAE/ml sample) and antioxidant activity determined by 2,2-diphenyl-1picrylhydrazyl radical (DPPH) assay of syrup was significant $(P \leq 0.05)$ while it was not significant $(\mathrm{P}>0.05)$ on total flavonoid ( $\mathrm{mg} \mathrm{CE} / \mathrm{ml}$ sample). The highest total phenolic content was recorded by sweet sorghum syrup (1.87 mg GAE/ml sample) meanwhile, total flavonoid content varied between (1.09 and $1.36 \mathrm{mg} \mathrm{CE} / \mathrm{ml}$ sample). Results also cleared that G.T.54-9 sugarcane and Rex sweet sorghum syrup samples exhibited significant $(P \leq 0.05)$ scavenging activity compared to commercial sugarcane sample that gave lower scavenging activity $(97.16,96.07$ and 74.22 , respectively). Sweet sorghum and sugarcane syrups sig- nificantly affected $(P \leq 0.05)$ absolute weight of organs and relative weight of both heart and kidney, while the effect on relative weight of liver was not significant $(P>0.05)$. The treatment of sweet sorghum and sugarcane syrups during cadmium acetate administration in rats led to reduction in alanine transaminase (ALT), aspartate transaminase (AST), antioxidant enzymes, urea, creatinine and biomarkers in rat livers, like reduced glutathione, catalase, malondialdehyde, serum total triglyceride, total cholesterol, high density lipoprotein cholesterol and low density lipoproteins cholesterol back near to normal when compared to control rats. In general, the treatment with sugarcane syrup reduced the cadmium acetate induced hepatotoxicity in rats.

Key words: sweet sorghum syrup, sugarcane syrup, cadmium, oxidative stress, rats

\section{INTRODUCTION}

Sweet sorghum [Sorghum bicolor (L.)Moench] which also names sugar sorghum, is a variety of common grain sorghum belongs to kingdom Plantae, family Poaceae and genus Sorghum. Sweet sorghum is characterized with sugary juice rich stalks so the essence of sweet sorghum is for its stalk that contains high amount of sugar and suitable for cultivation wherever temperatures do not fall below $15^{\circ} \mathrm{C}$. Sorghum syrup is a natural sweetener that tastes like molasses, but is slightly less sweet. Sweet sorghum crop could be considered as a source of syrup and can be used as sugar alternative for meeting certain requirements of the food industry Kulkarni et al (2018). 
Sugarcane (Saccharum spp.) is a perennial grass and one of the few plants which stores its carbohydrate reserves as sucrose Verheye, (2010).

The freshly extracted sugarcane juice was boiled vigorously till most of the water evaporated and juice gets concentrated as syrup and the temperature starts rising steadily to around $105^{\circ} \mathrm{C}$. Sugarcane juice was concentrated to syrup corresponding to TSS of syrup having an end point of $70^{\circ}$ Brix. The syrup was filtered using muslin cloth, cooled and packed in different packaging materials (thermally sealed polyethylene bags, PET polyethylene terephthalate jars and glass bottles) for six month at room temperature ranging $32-37^{\circ} \mathrm{C}$ as reported by Thilagavathi and Hemalatha, (2016). Authors also reported that sugarcane syrup is a unique natural product which meets the need of a target public in search of a healthier nutrition as it characterized by its high energy carbohydrates and rich in iron, calcium and phosphorous content. Consumption of sugarcane syrup is reported to build up resistance to disease and colds. Also sugarcane syrup is high in policosanol, which has been proven effective at reducing cholesterol levels. Therefore, the nutritional potential of sugarcane syrup as an alternative sweetening agent to sugar and jaggery is recommended.

Sweet sorghum stalks were harvested; leaves and panicles were separated stalks then were chopped pieces (about $10 \mathrm{~cm}$-long). The juice was extracted by manual milling procedures, then it was filtered through a screen and finally collected into 1 liter volume sterile flasks. The extracted juice was used for syrup production where $100 \mathrm{~mL}$ of juice was heated up to $50-75^{\circ} \mathrm{C}$ in a double-walled Erlenmeyer flask, juice was then clarified and evaporation was carried out under vacuum at 50 $75^{\circ} \mathrm{C}$ in two steps as follow: after solubility limit of liquor was reached it was filtered through a microfilter with pore size 0.45 -micrometer, then the concentration was continued until syrup reached 65-70 obrix. Syrup physiochemical and sensory properties were evaluated immediately after processing as stated by Cséfalvay and Bakacsi, (2019).

Cadmium ( $\mathrm{Cd}$ ) is considered as one of the most occupational toxic metals, and it is widely abundant in the environment. Humans and both plants and animals had the ability toabsorb cadmium and concentrate within their tissues efficiently Talas et al (2008).
Exposure to cadmium was reported to produce lipid peroxidation which considered as one of the main reasons of oxidative damage (Zhou et al 2009). Chronic exposure to cadmium led to increased free radical load, increased level of peroxidation products and reduced level of glutathione in rabbit models Pathak and Khandelwal, (2007).

The accumulated cadmium acetate causes an increased permeability to the hepatocyte membrane. Thus, consequently both the enzymes are released into the blood stream and thus the level was elevated Kataoka et al (2002).

One of the most sensitive toxicity indicators is organ weight that changes before other morphological changes. Physiological and pathological state in human and animals can be determined by recording change in organ weight, to diagnose whether the organ was exposed to the hurt or not the relative organ weight needed to be calculated (Vaghasiya et al 2011). Metabolic reaction caused by toxicants affect the different primary organs i.e heart, kidney and liver Dybing et al (2002).

Sho et al (1981) reported that the effect of sugarcane rind on the body weight change was significantly low. The food consumption, feed conversion and liver weight of each experimental group were similar. The concentrations of serum cholesterol, phospholipids and triglycerides, results cleared that the total cholesterol and phospholipids levels of the rats fed on corn oil group was the lowest followed by sugarcane rind diet group, triglycerides level of sugarcane rind diet group was the lowest and followed by cholesterol-free diet group, rats fed on corn oil group and rats fed on lard with cholesterol diet group, respectively).

Khan et al (2018) studied the hepatoprotective properties of sugarcane (Saccharum officinarum. L) juice in mice on hepatotoxicity where mice was given sugarcane juice $15 \mathrm{ml} / \mathrm{kg} /$ day for 30 days. Sugarcane juice significantly lowered the raise in aminotransferases (alanine transaminase and aspartate transaminase) and alkaline phosphatase (ALP) levels, which show the liver functional status. Also, sugarcane juice was found to be more effective as a hepatoprotective agent than vitamin $C$ in induced oxidative liver injury.

The aim of the current study was to evaluate the biological activity of sweet sorghum and sugarcane syrups as antioxidants source on lipid peroxidation, oxidative stress biomarkers and the lipid profile in male rats. 

stress induced by cadmium in albino rats

\section{MATERIALS AND METHODS}

\section{Materials}

Sweet sorghum (Sorghum bicolor, L., Moench) stalks (50-100 stalks) Rex variety was obtained from Giza station, Agricultural Research Centre (ARC), Giza, Egypt, during (2015-2016), while sugarcane variety Giza Taiwan54-9 (G.T. 54-9) Known as C9 was obtained from Malawi station, Minya government, Egypt during (2015-2016).

Sweet sorghum (Sorghum bicolor, L., Moench) stalks were harvested at dough stage (after 115 to 120 days from planting), while sugarcane was harvested after 12 months from planting. In addition, a representative sample of sugarcane commercial syrup was obtained from local market.

\section{Preparation of sweet sorghum and sugarcane syrups}

Juice was extracted and concentrated according to (Awad-Allah et al 2010) as follows:

\section{Juice extraction}

The chosen 25-50 stalks were stripped, cleaned and squeezed by an electric three roller horizontal mill with crushing capacity (9.00 and $10.38 \mathrm{Kg}$ for sweet sorghum and sugarcane G.T. 54-9 variety, respectively) to provide enough amount of juice. The extracted juice was filtrated twice using fine mesh screen $(0.5 \mathrm{~mm})$ in order to remove the suspended matter and collected into a stainless steel pans then stored at deep freezer (Electrostar) for three hours till concentration process.

\section{Juice concentration}

Five kilograms juice that have total soluble solids (TSS) 15.83 and $27.16 \%$ for sweet sorghum and sugarcane, respectively were evaporated by using stainless steel pans (6 liters capacity) till boiling point $\left(102 \pm 5^{\circ} \mathrm{C}\right.$ ) on direct flame for 7-8 hours till total soluble solids reached $40-50 \%$; then the concentration was completed on indirect heat (hot plate) for 5-6 hours. Skim removed during concentration in order to produce high quality syrup. The boiling temperature and TSS of final syrup were $106 \pm 2^{\circ} \mathrm{C}, 76.33,77.00 \%$ brix for sweet sorghum and sugarcane syrups, respectively. Brix was determined using sugar refractometer. The final syrup was filtered through two layers of clean cheesecloth in order to remove impurities and packed in one kilogram jar and cooled in refrigerator at $4 \pm 1^{\circ} \mathrm{C}$.

\section{Chemicals and Reagents}

Cadmium acetate dehydrate (98\%) was purchased from Technogene group Co., El-DokkiGiza, Egypt.

Kits of aspartate transaminase (AST), alanine transaminase (ALT), triglycerides (TG), creatinine, urea, cholesterol, high-density lipoprotein, reduced glutathione $(\mathrm{GSH})$ and lipid peroxidation were obtained from Biodiagnostic Co., El-Dokki, Giza, Egypt.

Total phenols and total flavonoids assays for extracted juice and syrup prepared from different varieties of sweet sorghum and sugarcane

The Folin- Ciocalteu method was used for the determination of total phenols and total flavonoids content was evaluated according to a colorimetric assay with aluminium chloride. The concentration of total phenolics is expressed as gallic acid equivalent per $1 \mathrm{ml}$ fresh sample while catechin was used as the standard for the construction of a calibration curve and expression of total flavonoid concentrations as catechin equivalent per $1 \mathrm{ml}$ fresh sample. All samples were prepared in triplicate as reported by Ivanova et al (2010).

Identification of phenolic and flavonoid compounds for extracted juice and syrup prepared from different varieties of sweet sorghum and sugar cane

To identify phenolic acids and flavonoids by HPLC, samples were prepared according to the method described by Jakopič et al (2009). All chromatograms were plotted at $280 \mathrm{~nm}$ to estimate phenolic acids and at $330 \mathrm{~nm}$ for flavonoids. All components were identified and quantified by comparison of peak areas with external standards as mentioned by Schieber et al (2001).

\section{Determination of DPPH scavenging activity}

The scavenging capacity of juice and syrup prepared from different sweet sorghum varieties and sugarcane extracts against 2,2-diphenyl-1picrylhydrazyl(DPPH) were determined according to Makori, (2013). Inhibition of free radical DPPH (\%) was calculated using the formula: according to Ayoola et al (2008). 
Percentage inhibition $(\%)=$

$$
\left.\left[\left(A_{\text {control }}-A_{\text {sample }}\right) / A_{\text {control }}\right)\right] \times 100
$$

$A$ control: is the absorbance at $517 \mathrm{~nm}$ of the control reaction (containing all reagents except test samples)

A sample: is the absorbance at $517 \mathrm{~nm}$ of the test samples.

\section{Animals and experimental design}

Thirty-two adult male Wistar albino rats, weighing160-180 g were obtained from Food Technology Research Institute, Agricultural Research Center, Giza, Egypt, and housed in cages at rooms maintained at $25 \pm 1^{\circ} \mathrm{C}$ with alternating cycles of light and dark of $12 \mathrm{~h}$ duration, tab water and standard animal feed diet were given ad-libitum. The compositions of standard diets are shown in Table (1) according to AIN-93 guidelines (Reeves, et al 1993).

After adaptation period for one week, rats were placed randomly into four groups of 8 each and administrated orally daily for 30 days as follows: (I) control group was received standard diet and tab water ad-libitum daily, (II) cadmium treated group: cadmium acetate solution $(10 \mathrm{mg} / \mathrm{L})$ was received in drinking water, (III) sweet sorghum (500 ppm) syrup solution was received once daily at a dose of $1 \mathrm{ml} / \mathrm{kg}$ body weight using an oral by gavage and cadmium solution also received daily, (IV) sugarcane syrup (500 ppm) solution was received once daily at a dose of $1 \mathrm{ml} / \mathrm{kg}$ body weight through oral by gavage also cadmium solution was received daily according to Zhang et al (2009) and Kadam et al (2008).

Blood samples were collected from the retroorbital plexus from all animals of each group into clean, dry and labeled tube $(5 \mathrm{ml})$. The tubes were centrifuged (123 XG for $15 \mathrm{~min}$.) to separate serum, which was tightly kept in sealed aliquot $5 \mathrm{ml}$ tubes on deep freezer at $-18 \stackrel{\circ}{\circ}$ until biochemical assays. At the end of the experiment (one month), rats were sacrificed and organs were excised and weighted. One gram of liver was used for liver biochemical analyses as described by Brown and Jeffries, (1975).

The relative organ weight of each animal was then calculated according to Aniagu et al (2005) as follows:

\section{Relative organ weight $=$} Absolute organ weight (g) $\times 100$

Body weight of rat on sacrifice day $(g)$
Table 1. Ingredients of the commercial balanced ration for growing (For one $\mathrm{Kg}$ pellet ration)

\begin{tabular}{|l|l|}
\hline \multicolumn{1}{|c|}{ Crude matter } & \multicolumn{1}{c|}{ Quantity } \\
\hline Crude protein & Not less than $17 \%$ \\
Crude fat & Not less than $2.4 \%$ \\
Crude fibers & Not more than $12 \%$ \\
Digestible energy & Not less than 2800 Kcal. \\
Vitamin A & $10000 /$. I. /Kg Ration \\
Vitamin K & $2 \mathrm{mg} / \mathrm{Kg}$ Ration \\
Vitamin D3 & $900 \mathrm{I.U} . / \mathrm{Kg}$ Ration \\
Vitamin E & $50 \mathrm{mg} / \mathrm{Kg}$ Ration \\
Folic acid & $5 \mathrm{mg} / \mathrm{Kg}$ Ration \\
Choline & $1200 \mathrm{mg} / \mathrm{Kg}$ Ration \\
Biotin & $0.2 \mathrm{mg} / \mathrm{Kg}$ Ration \\
Vitamin B12 & $0.01 \mathrm{mg} / \mathrm{Kg}$ Ration \\
Niacin & $50 \mathrm{mg} / \mathrm{Kg}$ Ration \\
Vitamin B6 & $2 \mathrm{mg} / \mathrm{Kg}$ Ration \\
Pantothenic acid & $20 \mathrm{mg} / \mathrm{Kg}$ Ration \\
Vitamin B2 & $6 \mathrm{mg} / \mathrm{Kg}$ Ration \\
Zinc & $70 \mathrm{mg} / \mathrm{Kg}$ Ration \\
Cobalt & $0.1 \mathrm{mg} / \mathrm{Kg}$ Ration \\
Manganese & $8.5 \mathrm{mg} / \mathrm{Kg}$ Ration \\
Iron & $75 \mathrm{mg} / \mathrm{Kg}$ Ration \\
\hline
\end{tabular}

\section{Biochemical Analysis}

\section{Liver function parameters}

The activities of alanine aminotransferase (ALT) and aspartate aminotransferase (AST) were determined colorimetrically according to Reitman and Frankel, (1957) method.

\section{Kidney function parameters}

\section{(a) Urea concentration:}

Enzymatic colorimetric determination of urea was carried out according to the method of Searcy el al (1967). While, Creatinine concentration determined kinetic according to the method of Henry, (1974).

\section{(b) Creatinine concentration}

Kinetic determination of creatinine was carried out according to the method of Henry, (1974).

\section{Lipid profiles parameters}

Enzymatic determination of cholesterol was carried out according to the method of Allain et al (1974); Fully enzymatic determination of total triglycerides was determined according to the method of Fossati and Prencipe, (1982). 

stress induced by cadmium in albino rats

Low density lipoproteins cholesterol (LDL-C) calculated according to Friedewald et al 1972 using the following equation:

\section{LDL-cholesterol = Total cholesterol - (HDL- cholesterol) - (Triglycerides $/ 5$ )}

Also, High Density Lipoprotein (HDL) serum cholesterol was determined using enzymatic colorimetric methods according to Lopez-Virella et al (1977).

\section{Determination of oxidative stress biomarkers}

\section{(a) Lipid Peroxidation}

The extent of lipid peroxidation in the liver was determined by measurement of malondialdehyde formation at $534 \mathrm{~nm}$ using the thiobarbituric acid reactive substances method as described by Ohkawa et al (1979).

\section{(b) Reduced glutathione (GSH)}

Reduced glutathione was determined according to the method of Beutler et al (1963).

\section{(c) Catalase activity in liver homogenates}

Catalase activity was assayed by the method described by Bonaventura et al (1972).

\section{Statistical analysis}

Statistical analyses were performed using SPSS statistical software package. Normality and homogeneity of the data was confirmed before ANOVA, differences among the experimental groups were assessed by one-way ANOVA followed by Duncan's multiple range test with $P \leq$ 0.05 being considered statistically significant Snedecor and Cochran, (1980).

\section{RESULTS AND DISCUSSION}

Data illustrated in Table (2) cleared that the effect of variation in varieties on total phenol $(\mathrm{mg}$ $\mathrm{GAE} / \mathrm{ml}$ sample) and antioxidant activity determined by 2,2-diphenyl-1-picrylhydrazyl radical (DPPH) assay of syrup was significant $(P \leq 0.05)$ while it was not significant $(P>0.05)$ on total flavonoid (mg CE/ml sample).

As shown in Table (2), total phenols were significantly $(P \leq 0.05)$ decreased after juice concentration in all samples except for Rex variety which exhibited the highest phenol content $(1.87 \mathrm{mg}$ $\mathrm{GAE} / \mathrm{ml}$ sample) meanwhile, total flavonoid content varied between ( 1.09 and $1.36 \mathrm{mg} \mathrm{CE} / \mathrm{ml}$ sample). These results are close to those obtained by Asikin et al (2018).

Results also cleared that G.T.54-9 sugarcane and Rex sweet sorghum syrup samples exhibited significant $(\mathrm{P} \leq 0.05)$ scavenging activity compared to commercial sugarcane sample that gave lower scavenging activity $(97.16,96.07$ and 74.22 , respectively). These results might be due to solubility differences of flavonoids in a micellar water-lipid system that may influence results obtained. These results agree with Feng et al (2014). From these results it could be concluded that the syrups of sweet sorghum and sugarcane are strong free radical scavengers.

Table 2. Total phenol, total flavonoid contents and scavenging activity of juice concentrate (Syrup) from sweet sorghum and sugarcane

\begin{tabular}{|c|c|c|c|}
\hline \multirow[b]{2}{*}{ Character } & \multirow{2}{*}{$\begin{array}{c}\text { Sweet sorghum Rex } \\
\text { variety }\end{array}$} & \multicolumn{2}{|c|}{ Sugar cane samples } \\
\hline & & G. T.54-9 & Commercial \\
\hline Total phenol (mg GAE/ml sample)* & $1.87^{\mathrm{a}}$ & $0.98^{b}$ & $0.29^{c}$ \\
\hline Total flavonoid (mg CE/ml sample) ${ }^{\star *}$ & $1.36^{\mathrm{a}}$ & $1.09^{a}$ & $1.35^{\mathrm{a}}$ \\
\hline DPPH scavenging activity (\%) & $96.07^{a}$ & $97.16^{a}$ & $74.22^{b}$ \\
\hline
\end{tabular}

Means with different letters within each row are significantly different at $(\mathrm{p} \leq 0.05)$. * Data are expressed as $\mathrm{mg}$ Gallic acid equivalents (GAE) per $\mathrm{ml}$ of sample. ${ }^{* \star}$ Data are expressed as $\mathrm{mg}$ of catechin acid equivalent (CE) per $\mathrm{ml}$ of sample. , DPPH: (2,2-diphenyl-1-picrylhydrazyl radical), 
Bioactive compounds (phenolic and flavonoid compounds) existing in different sweet sorghum and sugarcane syrups

Data in Table (3) illustrated that, Rex variety recorded the highest content of almost phenolic compounds and all flavonoid compounds. Among sugarcane samples, pyrogallol, chlorogenic, evanilic, ferulic and ellagic were predominant in G.T 54.9 sugarcane syrup $(469.49,59.90,88.70,53.90$ and 56.86, respectively). On contrary commercial sugarcane sample exhibited the lowest content of phenolic content. The increase in phenolic content might be due to the effect of high temperature that accelerate concentration of solids including higher content of phenolic substances meanwhile, the high content of ferulic acids probably due to the degradation of lignin and hemicellulose materials. While the degradation of the hydroxyl cinnamic acid derivatives during concentration process led to an increase in benzoic acid. These results are in harmony with Payet et al (2006).

Regarding flavonoid content of different syrup samples, data Table (3) cleared that flavonoid compounds were increased after concentration, the dominant flavonoids in Rex syrup were naringin (110.6 ppm), hisperdin (47.35 ppm), hispertin (46.31 ppm), rosmarinic (37.30 ppm) and quercetrin (21.36 ppm), respectively. As shown in Table (3) in spite of low flavonoid content recorded by G.T. 54-9 sugarcane syrup but it exhibited a higher content of naringin and quercetin (236.53 and 4.66 ppm, respectively). On contrary, commercial sugarcane syrup exhibited the highest content of hisperdin (263.08 ppm), narengenin (159.95 ppm), rutin $(104.63 \mathrm{ppm})$, hispertin $(92.26 \mathrm{ppm})$, quercetrin (54.93 ppm), kampherol (28.42 ppm) and apegnin (3.04 ppm). Finally, the results indicated that the examined extracts contained specific amounts of polyphenol and flavonoid compounds, proving them to be perfect sources of antioxidants. The variation in flavonoid content might be due to different techniques of extraction and processing that might affect the antioxidant capacity measured in different materials also genetic factors, different environmental conditions, stage of maturity, cultivar or varietals differences, soil fertilization and the part of the plant used, amongst other factors that affect quantitative variation in these phytochemicals (Herrman, 1976).

Body weight gain of rats as affected by syrup of sweet sorghum and sugarcane and/or cadmium acetate

Data in Fig. (1) illustrated that the differentiation of initial body weight among rat groups. The highest body weight was recorded by group III, followed by Group I then Group IV and Group II (162.40, 158.20, 146.60 and $144.60 \mathrm{~g}$, respectively). During experiment duration, it was noticed that, body weight gain non significantly $(p>0.05)$ differed by treatments. These results may be due to the stress that roughly reduce food intake consequently body weight Martı' et al (1994) or stress levels, genetics, amount of sleep that led to sudden change in calorie and weight-loss formula. Meanwhile, the effect of time was significant $(p \leq 0.05)$ among all treatments, where body weight gain decreased as time increased among all treatments. These results probably due to exposure to stress that induce reduction in body weight that can continue even if the food intake returned to normal condition. These results are in harmony with Valle`s et al (2000). 

stress induced by cadmium in albino rats

Table 3. Fractionation of bioactive compounds (ppm) in sweet sorghum and sugarcane juice concentrates (Syrups)

\begin{tabular}{|c|c|c|c|}
\hline \multirow{2}{*}{ Samples Bioactive } & \multirow{2}{*}{ Sweet sorghum Rex variety } & \multicolumn{2}{|c|}{ Sugarcane samples } \\
\hline & & Giza Taiwan 54-9 & Commercial \\
\hline \multicolumn{4}{|c|}{ Phenolic Compounds (ppm) } \\
\hline Gallic & 33.80 & 6.96 & 1.42 \\
\hline Pyrogallol & 726.67 & 469.49 & 23.67 \\
\hline 4-Amino-benzoic & 20.88 & 3.76 & 0.23 \\
\hline Protocatchuic & 110.06 & 19.00 & 1.67 \\
\hline Chlorogenic & 244.96 & 59.90 & 0.67 \\
\hline Catecol & 172.18 & 21.42 & 2.22 \\
\hline Catechen & 71.61 & 31.10 & 0.21 \\
\hline Caffeine & 33.57 & 8.15 & 0.95 \\
\hline P-OH- benzoic & 165.73 & 49.02 & 2.10 \\
\hline Caffeic & 196.31 & 22.32 & 0.91 \\
\hline Vanillic & 92.30 & 8.88 & 0.48 \\
\hline Ferulic & 86.32 & 53.90 & 0.44 \\
\hline Iso-ferulic & 39.10 & 50.03 & 0.15 \\
\hline e-vanillic & 281.29 & 88.70 & 28.23 \\
\hline Reversetrol & 41.77 & ND & ND \\
\hline Ellagic & 63.35 & 56.86 & ND \\
\hline Alpha-coumaric & 10.62 & 4.56 & 7.80 \\
\hline Benzoic & 117.45 & 32.77 & ND \\
\hline Salycilic & 23.05 & 20.50 & 2.02 \\
\hline 3,4,5- mthoxy-cinnamic & 33.11 & 7.65 & 0.86 \\
\hline Coumarin & 15.31 & 5.13 & 0.30 \\
\hline p-coumaric & 13.84 & 4.05 & ND \\
\hline Cinnamic & 1.74 & 1.31 & 2.02 \\
\hline \multicolumn{4}{|c|}{ Flavonoid compounds (ppm) } \\
\hline Naringin & 101.06 & 236.53 & 159.95 \\
\hline Rutin & 24.68 & 13.97 & 104.63 \\
\hline Hisperdin & 47.35 & 16.28 & 263.08 \\
\hline Rosmarinic & 37.30 & 4.20 & 3.40 \\
\hline Quercetrin & 21.36 & 21.33 & 54.93 \\
\hline Quercetin & 2.88 & 4.66 & 3.54 \\
\hline Narengenin & 3.34 & 4.24 & 5.89 \\
\hline Kampherol & 1.63 & 1.35 & 28.42 \\
\hline Hispertin & 46.31 & 18.77 & 92.26 \\
\hline Apegnin & 0.78 & 0.20 & 3.04 \\
\hline
\end{tabular}

N.D: Not detected 


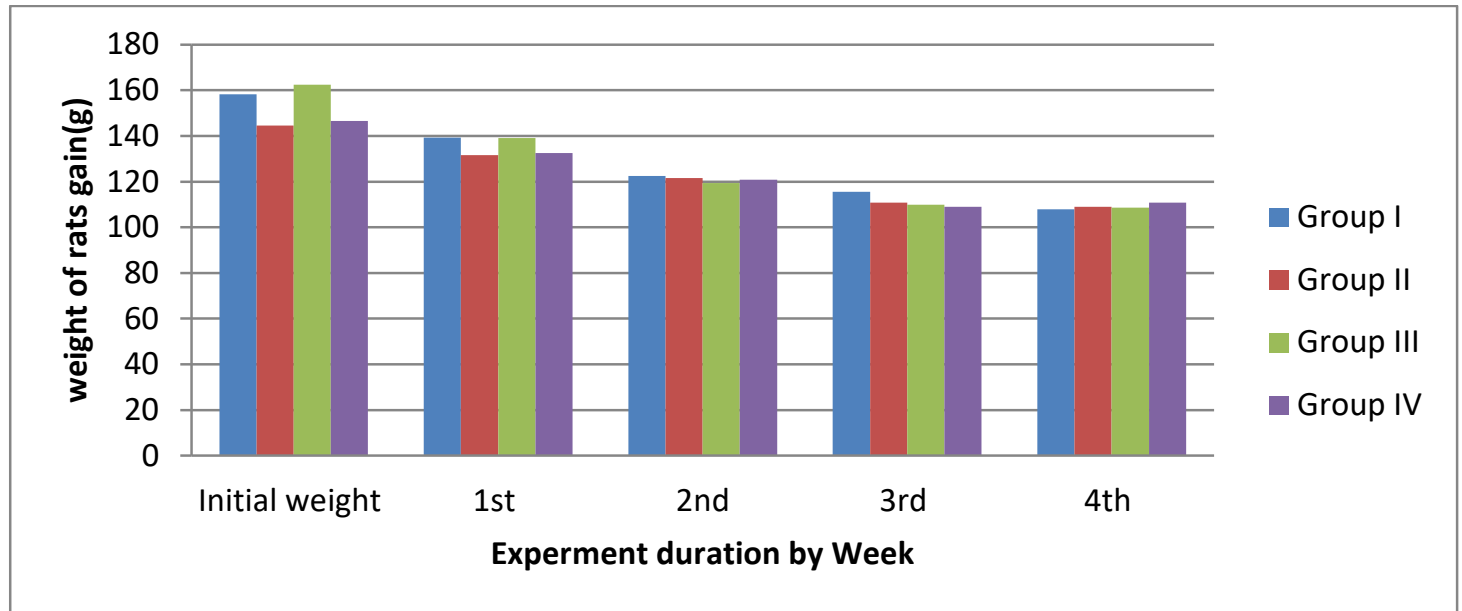

Fig. 1. Body weight gain ( $\mathrm{g}$ ) of rat's as affected by syrup of sweet sorghum and sugarcane and/or cadmium acetate during experiment duration (one month)

\section{Effect on internal organs relative weight of male albino rats as affected by different treatments}

Data in Table (4) showed that treatments had significant effect $(P \leq 0.05)$ on absolute weight of different rat organs and relative weight of both heart and kidney. On contrary, treatments had not significantly affect $(P>0.05)$ relative weight of liver. These differences may be due to different factors that may influence organ weights such as animal strain, age, gender, conditions of environment and experiment. Absolute weight of heart varied between 0.31 to $0.46 \mathrm{~g}$, kidney and liver varied between 0.52 to $0.67 \mathrm{~g}$ and 2.34 to $3.19 \mathrm{~g}$, respectively. The increase in liver's weight might be due to hepatocellular hypertrophy that refers to the toxic effect of cadmium acetate. Concerning relative weight of heart it was observed that, the highest value was found in group IV followed by group II then control and finally group III, respectively. The enlargement and increase in heart weight probably due to toxic effect of the cadmium that resulted in poor oxygen carriage so to pump more blood metabolic activities of the heart increased Ajani et al (2008). The highest relative weight of kidney was found in group III followed by group IV then control and finally group II, respectively. The variation in kidney weight might be associated with gender and age of animal. On the other hand, relative weight of liver varied between 2.26 to $2.88 \%$. These results probably due to proportional relationships exist between the liver weight and body weight Bailey et al (2004).

Table 4. Absolute and relative weight of rat's organs as affected by syrup of sweet sorghum and sugarcane and/or cadmium acetate

\begin{tabular}{|l|c|c|c|c|c|c|}
\hline \multirow{2}{*}{ Treatment } & $\begin{array}{c}\text { Absolute and Relative } \\
\text { weight }\end{array}$ & \multicolumn{3}{|c|}{$\begin{array}{c}\text { Absolute weight of organs } \\
\text { (g) }\end{array}$} & \multicolumn{3}{|c|}{ Relative weight of organs } \\
(\%)
\end{tabular}

Where: Group I: control group; Group II: cadmium treated group; Group III: sweet sorghum (500 ppm) syrup solution and cadmium-treated group; Group IV: sugarcane (500 ppm) syrup solution and cadmium-treated group - Means with different letters within each column are significantly different at $(p \leq 0.05)$ 

stress induced by cadmium in albino rats

\section{Liver and Kidney function of rats as affected by syrup of sweet sorghum and sugarcane and/or cadmium acetate}

Results in Table (5) revealed the functions of liver by measuring the activity of serum enzymes i.e. aspartate transaminase (AST) and alanine transaminase (ALT).

Cadmium acetate intoxication produced a significant $(P \leq 0.05)$ elevation of serum liver enzymes, ALT, AST compared to control rats $73.25,84.00$ and $31.75,35.25 \mathrm{IU} / \mathrm{ml}$, respectively. Generally, ALT, AST enzymes increased under liver damage Hung et al (2006). ALT and AST considered as specific marker enzymes that elevated under cadmium acetate induced toxicity Kowalczyk et al (2003).
All these mentioned changes were significantly $(P \leq 0.05)$ reduced to normal control rats upon sweet sorghum and sugarcane syrup treatments during cadmium acetate toxicities in rats (Group III and Group IV).

Same findings were observed regarding both urea and creatinine presented in Table (5). But all these conditions were reversed back near to normal in sweet sorghum and sugarcane syrup treated rats (Group III and Group IV) when compared to control rats. These results are in harmony with that obtained by (Khan et al 2018). The normal serum creatinine level was found to be 0.5 to $1.0 \mathrm{mg} / \mathrm{dL}$ according to daily diet and activity as mentioned by Hamilton et al (1972).

Table 5. Liver and Kidney function of rats as affected by syrup of sweet sorghum and sugarcane and/or cadmium acetate

\begin{tabular}{|l|c|c|c|c|}
\hline & $\begin{array}{c}\text { Liver and kidney } \\
\text { functions }\end{array}$ & \multicolumn{2}{|c|}{ Liver } & \multicolumn{2}{|c|}{ Kidney } \\
\cline { 3 - 5 } Treatment & ALT(IU/ml) & AST (IU/ml) & Urea (mg/dL) & Creatinine(mg/dL) \\
\hline Group I & $31.75^{\mathrm{b}}$ & $35.25^{\mathrm{b}}$ & $39.50^{\mathrm{b}}$ & $0.50^{\mathrm{b}}$ \\
Group II & $73.25^{\mathrm{a}}$ & $84.00^{\mathrm{a}}$ & $62.00^{\mathrm{a}}$ & $0.69^{\mathrm{a}}$ \\
Group III & $35.00^{\mathrm{b}}$ & $36.50^{\mathrm{b}}$ & $43.25^{\mathrm{b}}$ & $0.54^{\mathrm{b}}$ \\
Group IV & $33.75^{\mathrm{b}}$ & $34.50^{\mathrm{b}}$ & $42.88^{\mathrm{b}}$ & $0.55^{\mathrm{ab}}$ \\
\hline
\end{tabular}

Where: Group I: control group; Group II: cadmium treated group; Group III: sweet sorghum (500ppm) syrup solution and cadmium-treated group; Group IV: sugarcane (500 ppm) syrup solution and cadmium-treated group

- Means with different letters within each column are significantly different at $(p \leq 0.05)$

-ALT = Alanine aminotransaminase; $\mathrm{AST}=$ Aspartate aminotransaminase

Oxidative stress biomarkers of rats as affected by syrup of sweet sorghum and sugarcane and/or cadmium acetate

The level of antioxidant enzymes and biomarkers in rat livers like reduced glutathione, catalase and malondialdehyde in normal, cadmium acetate treated, sweet sorghum and sugarcane treated rats are illustrated in Table (6). Results showed that the activity of reduced glutathione and catalase enzymes were significantly $(P \leq 0.05)$ decreased in cadmium acetate group, the decrease is probably due to irreversible damage of the enzyme by reactive oxygen species- i.e. peroxides, superoxide and hydroxyl radical- produced as a result of stress. The levels of antioxidant enzymes returned near to normal in rats treated with sweet sorghum and sugarcane syrups.
As for malondialdehyde results, it could be noted that malondialdehyde level in rats treated with cadmium was significantly $(\mathrm{P} \leq 0.05)$ higher than that in control rats 245.68 and $167.25 \mathrm{nmol} / \mathrm{g}$ tissue, respectively. These results point out that production of oxygen free radicals in rats increased. Also, it could be noticed that conditions were reversed near to normal in sweet sorghum and sugarcane syrups treated (Group III and Group IV) rats when compared to control rats. These results are in harmony with those obtained by Abbassy et al (2014).

In general, it was found that treatment with sweet sorghum and sugarcane syrups reduced the cadmium acetate induced hepatotoxicity and lipid peroxidation in rats. This might be due to presence of low molecular weight compounds such as polyphenols that can interrupt the propagation of free radical reactions and stop lipid peroxidation chain reaction Acworth et al (1997). 
Table 6. Oxidative stress biomarkers of rat's liver as affected by syrup of sweet sorghum and sugarcane and/or cadmium acetate

\begin{tabular}{|l|c|c|c|}
\hline Character & $\begin{array}{c}\text { Reduced Glutathione } \\
(\mathbf{m M} / \mathbf{g})\end{array}$ & $\begin{array}{c}\text { Catalase }(\mu \mathrm{mol} / \mathbf{m g} \\
\text { tissue) }\end{array}$ & $\begin{array}{c}\text { Malondialdehyde } \\
\text { (nmol/g tissue) }\end{array}$ \\
\hline Group I & $21.63^{\mathrm{a}}$ & $49.73^{\mathrm{a}}$ & $167.25^{\mathrm{c}}$ \\
Group II & $12.73^{\mathrm{c}}$ & $39.53^{\mathrm{c}}$ & $245.68^{\mathrm{a}}$ \\
Group III & $17.95^{\mathrm{b}}$ & $46.73^{\mathrm{b}}$ & $183.55^{\mathrm{b}}$ \\
Group IV & $18.00^{\mathrm{b}}$ & $48.0^{\mathrm{ab}}$ & $168.23^{\mathrm{c}}$ \\
\hline
\end{tabular}

Where: Group I: control group; Group II: cadmium treated group; Group III: sweet sorghum (500 ppm) syrup solution and cadmium-treated group; Group IV: sugarcane (500 ppm) syrup solution and cadmium-treated group

- Means with different letters within each column are significantly different at $(p \leq 0.05)$

Lipid profile of rats as affected by syrup of sweet sorghum and sugarcane and/or cadmium acetate

Data in Table (7) pointed out that after one month experimental period, cadmium treatment significantly $(P \leq 0.05)$ increased the serum levels of total cholesterol, triglycerides, low density lipoprotein cholesterol while serum high density lipoprotein cholesterol significantly $(\mathrm{P} \leq 0.05)$ decreased compared to other groups. These results may be due to oxidative stress induced by cadmium acetate that led to a disorder in the balance of pro- oxidant and antioxidant which led to disease expansion, cell damage, in convenient biological reactions. These results indicated that oral administration of cadmium significantly affected the adverse metabolic effects in rats after one month. The results agreed with Olisekodiaka et al (2012).

On the other hand, treatment with sweet sorghum and sugarcane syrups (Group III and Group IV) led to reduction of total cholesterol, triglycerides, low density lipoprotein cholesterol and serum high density lipoprotein cholesterol back near to normal levels when compared to control group.

Table 7. Lipid Profile of rats as affected by syrup of sweet sorghum and sugarcane and/or cadmium acetate

\begin{tabular}{|c|c|c|c|c|}
\hline $\begin{array}{ll}\text { Treatment } & \text { Character } \\
\end{array}$ & $\begin{array}{c}\text { Triglycerides (TG) } \\
\mathrm{mg} / \mathrm{dL}\end{array}$ & $\begin{array}{c}\text { Total Cholesterol (TC) } \\
(\mathrm{mg} / \mathrm{dL})\end{array}$ & $\begin{array}{l}\text { HDL-C } \\
(\mathrm{mg} / \mathrm{dL})\end{array}$ & $\begin{array}{l}\text { LDL-C } \\
\text { (mg/dL) }\end{array}$ \\
\hline Group I & $29.75^{b}$ & $175.50^{b}$ & $22.45^{\mathrm{a}}$ & $147.10^{c}$ \\
\hline Group II & $46.1^{\mathrm{a}}$ & $206.50^{a}$ & $13.50^{d}$ & $183.73^{a}$ \\
\hline Group III & $30.18^{b}$ & $180.50^{b}$ & $17.00^{c}$ & $157.47^{b}$ \\
\hline Group IV & $30.10^{b}$ & $180.50^{b}$ & $19.20 \mathrm{~b}$ & $155.28^{b}$ \\
\hline
\end{tabular}

Where: Group I: control group; Group II: cadmium treated group; Group III: sweet sorghum $\quad$ (500 ppm) syrup solution and cadmium-treated group; Group IV: sugarcane (500 ppm) syrup solution and cadmium-treated group

- Means with different letters within each column are significantly different at $(p \leq 0.05)$

-HDL-C: High-Density Lipoprotein cholesterol; LDL-C: Low-Density Lipoprotein cholesterol. 

stress induced by cadmium in albino rats

\section{CONCLUSION}

In conclusion, results cleared that the most sensitive organ target for toxicity is liver. Effect of oxidative stress on absolute, relative weights of organs, oxidative stress biomarkers and lipid profile in rats experimental groups was evaluated by using sweet sorghum and sugarcane syrups as protective materials instead of juice as in previous studies. Results cleared that sweet sorghum and sugarcane syrups significantly reduced the side effects of cadmium toxicity.

\section{REFERENCES}

Abbassy M.A., Marzouk M.A., Mansour S.A., Shaldam H.A. and Mossa A.H. 2014. Impact of Oxidative Stress and Lipid Peroxidation Induced by Lambda-cyhalothrin on P450 in Male Rats: The Ameliorating Effect of Zinc. J. Environ. Anal. Toxicol. 4(4), 1-5.

Acworth I.N., McCabe D.R. and Maher T.J. 1997. The analysis of free radicals, their reaction products, and antioxidants. In: Antioxidants, Oxidants and Free Radicals. Baskin $\mathbf{S}$ and Salem H, editors. London, UK, pp. 23-77.

Ajani E.O., Shallie P.D., Adegbesan B.O., Salau B.A. and Adesanya M. 2008. Protective effect of Garcinia Kola. (Kolaviron) extract on predisposition of rats to cardiovascular diseases following separate administration of amodiaquine and artesunate. Afr. J. Traditional Complementary and Alternative Medicines 5(2), 180186.

Allain C.C., Poon L.S., Chan C.S.G., Richmond W. and Fu P.C. 1974. Enzymatic determination of total serum cholesterol. Clin. Chem. 20(4), 470-475.

Aniagu S.O., Nwinyi F.C., Akumka D.D., Ajoku G.A., Dzarma S., Izebe K.S., Ditse M., Nwaneri P.E.C., Wambebe C. and Gamaniel K. 2005. Toxicity studies in rats fed nature cure bitters. African J. of Biotechnology. 4 (1), $72-$ 78.

Asikin Y., Wada K., Imai Y., Kawamoto Y., Mizu M., Mutsuura M. and Takahashi M. 2018. Compositions, taste characteristics, volatile profiles, and antioxidant activities of sweet sorghum (Sorghum bicolor L.) and sugarcane (Saccharum officinarum L.) syrups. J. of Food Measurement and Characterization 12, 884891.
Awad-Allah M.N., Ferweez H. and Ibrahim S.M. 2010. Substitution of sugarcane with sweet sorghum stalks in black honey processing. J. Adv. Agric. Res. (Fac. Ag. Saba Basha). 15(2), 375392.

Ayoola G.A., Coker H.A.B., Adesegun S.A., Adepoju-Bello A.A., Obaweya K., Ezennia E.C., Atangbayila T.O. 2008. Phytochemical Screening and Antioxidant Activities of Some Selected Medicinal Plants Used for Malaria Therapy in Southwestern Nigeria.Tropical J. of Pharmaceutical Research 7(3), 1019-1024.

Bailey S.A., Zidell R.H. and Perry R.W. 2004. Relationships between organ weight and body / brain weight in the Rat: what is the best analytical endpoint?. Toxicologic Pathology. 32(4), 448-466.

Beutler E., Duron O. and Kelly B.M. 1963. Improved method for the determination of blood glutathione. J. of Laboratory and Clinical Medicine. 61, 882-888.

Bonaventura J., Schroeder W.A. and Fang S. 1972. Human erythrocyte catalase: an improved method of isolation and a reevaluation of reported properties. Archives of Biochemistry and Biophysics. 150(2), 606-617.

Brown P.L. and Jeffries C.D. 1975. Liver Glutathione and Glutathione Reductase Response of Endotoxin-Treated Mice. Infection and Immunity. 11(1), 8-13.

Cséfalvay E. and Zoltán Bakacsi Z. 2019. Chemical-free Processing of Sweet Sorghum Juice of Cultivar Sucrosorgho 506. Periodica Polytechnica Chemical Engineering 63(1), 36-50.

Dybing E., Doe J., Groten J., Kleiner J., Brien J.O., Renwick A.G., Schlatter J., Steinberg P., Tritscher A., Walker R. and Younes M. 2002. Hazard characterization of chemicals in food and diet: dose response, mechanism and extrapolation issues. Food Chem. Toxicol. 42(2-3), 237-282.

Feng S., Luo Z., Zhang Y., Zhong Z. and Lu B. 2014. Phytochemical contents and antioxidant capacities of different parts of two sugarcane (Saccharum officinarum L.) cultivars. Food Chem. 151, 452-458.

Fossati P. and Prencipe L. 1982. Serum triglycerides determined colorimetrically with an enzyme that produces hydrogen peroxide. Clin. Chem. 28(10), 2077-2080.

Friedewald W.T., Levi R.I. and Fredrickson D.S. 1972. Estimation of the concentration of low density lipoproteins cholesterol in plasma with- 
out use of the preparative ultracentrifuge. Clin. Chem. 18(6), 499-502.

Hamilton R.W., Gardner L.B., Penn A.S. and Goldberg M. 1972. Acute tubular necrosis caused by exercise-induced myoglobinuria. Annals of Internal Medicine. 77(1), 77-82.

Henry R.J. 1974. Creatinine Measurements with Colorimetric Method: Clinical Chemical Principles and Techniques, Vol. 525, Harper and Row Publishers, New York, USA, $2^{\text {nd }}$ Ed. pp. 549-550.

Herrmann K. 1976. Flavonol and flavones in food plants: a review. J. of Food Technology 11, 433-448.

Hung D.Y., Siebert G.A., Chang P., Whitehouse M.W., Fletcher L., Crawford D.H.G. and Roberts M.S. 2006. Hepatic pharmacokinetics of propranolol in rats with adjuvant - induced systemic inflammation. Am. J. Physiol. Gastrointest Liver Physiol. 290, G343-G351.

Ivanova V., Stefova M. and Chinnici F. 2010. Determination of the polyphenol contents in Macedonian grapes and wines by standardized spectrophotometric methods. J. Serb. Chem. Soc. 75(1), 45-59.

Jakopič J., Veberič R. and Štampar F. 2009. Extraction of phenolic compounds from green walnut fruits in different solvents. Acta Agriculturae Slovenica, 93(1), 11-15.

Kadam U.S.I., Ghosh S.B., De S., Suprasanna P., Devasagayam T.P.A. and Bapat V.A. 2008. Antioxidant activity in sugarcane juice and its protective role against radiation induced DNA damage. Food Chem. 106, 1154-1160.

Kataoka H., Horiyama S., Yamaki M., Oku H., Ishiguro K., Katagi T., Takayama M., Semma M. and Ito Y. 2002. Anti-inflammatry and antiallergic activities of hydroxylamine and related compounds. Biological and Pharmaceutical Bulletin. 25(11), 1436-1441.

Khan S.W., Ghafoor A. and Ahamd N. 2018. Hepatoprotective Properties of Sugarcane Juice and Vitamin $\mathrm{C}$ were compared in a Mouse Model of Liver Injury Induced by INH (Isoniazid). Pakistan J. of Medical and Health Sci. 12(2), 764-767.

Kowalczyk E., Kopff A., Fijalkowski P., Kopff M., Niedworok J., Blaszczyk J., Kedziora J. and Tyślerowizc P. 2003. Effect of anthocyanins on selected biochemical parameters in rats exposed to cadmium. Acta Biochim Pol. 50(2), 543-548.

Kulkarni D.B., Deshpande H.W., Sakhale B.K. and Pawar V.S. 2018. Sweet Sorghum Syrup as Natural Sweetener for Glazed Tamarind Candy. Int. J. Nutr. Sci. 3(2), 1023-1027.

Lopez-Virella M.F., Stone P., Ellis S. and Colwell J.A. 1977. Cholesterol determination in high-density lipoproteins separated by three different methods. Clin. Chem. 23(5), 882-884.

Makori E. 2013.The Potential of Sweet Sorghum [Sorghum Bicolor (L.)Moench] As A Bio- Resource for Syrup and Ethanol Production in Kenya. M. Sc. thesis. Jomo Kenyatta Univ. of Agric. and Technology, $53 \mathrm{p}$.

Martı' O., Martı' J. and Armario A. 1994. Effects of chronic stress on food intake in rats: influence of stressor intensity and duration of daily exposure. Physiol. Behav. 55(4), 747-753.

Ohkawa H., Ohishi W. and Yagi K. 1979. Assay for lipid peroxidation in animal tissues by thiobarbituric acid reaction. Analytical Biochemistry. 95(2), 351-358.

Olisekodiaka M.J., Igbeneghu C.A., Onuegbu A.J., Oduru R. and Lawal A.O. 2012. Lipid, lipoproteins, total antioxidant status and organ changes in rats administered high doses of cadmium chloride. Medical Principles and Practice. 21(2), 156-159.

Pathak N. and Khandelwal S. 2007. Role of oxidative stress and apoptosis in cadmium induced thymic atrophy and splenomegaly in mice. Toxicology Letters, 169(2), 95-108.

Payet, B.; Cheong, A. S. and Smadja, J. 2006. Comparison of the concentrations of phenolic constituents in cane sugar manufacturing products with their antioxidant activities. Journal of Agricultural and Food Chemistry. 54(19), 7270-7276.

Reeves P.G., Nielsen F.H. and Fahey G.C.Jr. 1993. AIN-93 purified diets for laboratory rodents: final report of the American Institute of Nutrition ad hoc writing committee on the reformulation of the AIN-76A rodent diet. J. Nutrition, 123(11), 1939-1951.

Reitman S. and Frankel S. 1957. A colorimetric method for the determination of serum GOT and GPT. American. J. Clin. Path. 28(1), 56-63.

Schieber A., Keller P. and Carle R. 2001. Determination of phenolic acids and flavonoids of apple and pearby high-performance liquid chromatography. J. of Chromatography A. 910(2), 265-273.

Searcy R.L., Reardon J.E. and Foreman J.A. 1967. Enzymatic colourimetric method of the determination of plasma urea, Amer. J. Clinc. Tech. 33, 15-20. 

stress induced by cadmium in albino rats

Sho H., Chinen L., Uchihara K. and Fukuda N. 1981. Effects of Okinawan sugarcane rind on serum and liver cholesterol and triglyceride levels in the rat. J. of Nutritional Sci. and Vitaminology. 27(5), 463-470.

Snedecor G.W. and Cochran W.G. 1980. Statistical methods $7^{\text {th }}$ ed. Lowa State University Press, Ames, lowa, USA.

Talas Z.S., Orun I., Ozdemir I., Erdogan K., Alkan A. and Yilmaz I. 2008. Antioxidative role of seleni-um against the toxic effect of heavy metals $\left(\mathrm{Cd}^{+2}, \mathrm{Cr}^{+3}\right)$ on liver of rainbow trout (Oncorhynchus mykiss Walbaum 1792). Fish Physiol. Biochem. 34(3), 217-222.

Thilagavathi T. and Hemalatha G. 2016. Evaluation of quality characteristics of sugarcane syrup. Int. J. of Nutrition and Agric. Research 3(2), 49- 55.

Vaghasiya Y.K., Shukla V.J. and Chanda S.V. 2011. Acute oral toxicity study of Pluchea arguta boiss extract in mice. J. of Pharmacology and Toxicology 6(2), 113-123.
Valle's A., Marti-sistac O., Garcı'a A. and Armario A. 2000. Single exposure to stressors causes long-lasting, stress-dependent reduction of food intake in rats. Am. J. Physiol. Regulatory Integrative Comp. Physiol. 279(3), R1138-R1144.

Verheye H.W. 2010. Soils, plant growth and crop production, Vol. I. Growth and Production of Sugarcane. National Sci. Foundation Flanders and Geography Dept., Univ. of Ghent, Belgium, pp. 208-241.

Zhang Y., Liu X., Lu H., Mei L. and Liu Z. 2009. Lipid Peroxidation and Ultrastructural Modifications in Brain after Perinatal Exposure to Lead and/or Cadmium in Rat Pups. Biomedical and Environmental Sci. 22, 423-429.

Zhou Y.J., Zhang S.P., Liu C.W. and Cai Y.Q. 2009. The protection of selenium on ROS mediated-apoptosis by mitochondria dysfunction in cadmium-induced LLC-PK (1) cells.Toxicol. In Vitro. 23(2), 288-294. 


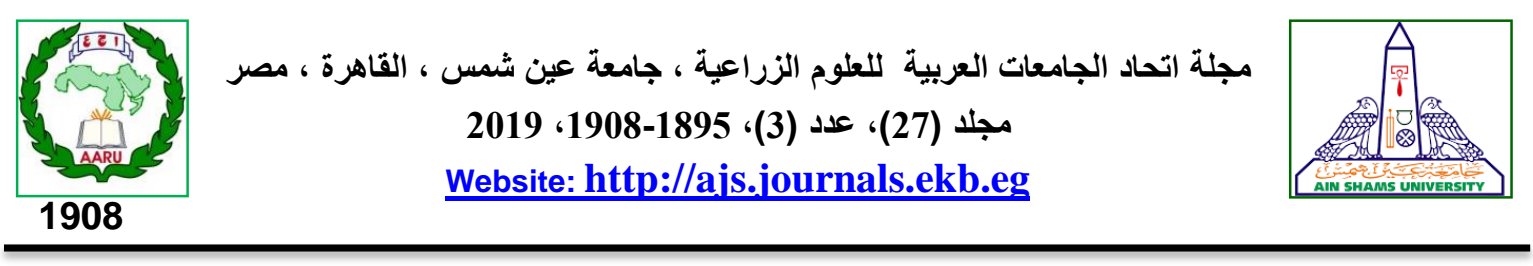

النشاط الوقائي لثراب كل من الذرة الرفيعة السكرية و قصب السكر ضد الإجهاد التأكسدي المُستحث بإستخدام الكادميوم فى الفئران البيضاء

[151]

يارا إبراهيم حنفى الجداوى1" - السيد إبراهيم يوسف2 - نسرين محمد نبيه يسن2

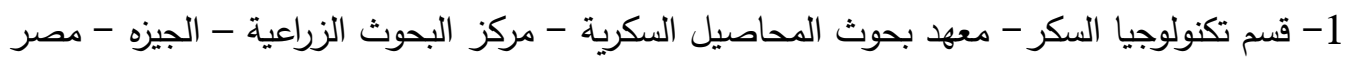

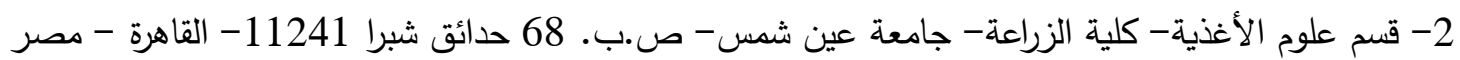
*Corresponding author: yara_elgeddawy@yahoo.com

Received 16 May, 2019

Accepted 12 June, 2019

و 1.36 ملجم CE/مل عينه), كما أوضحت النتائج أن شراب كل من الذرة الرفيعة السكرية وشراب قصب أوضب

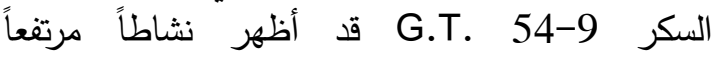
كمضادات للأكسدة مقارنة بعينة قصب السكر التجارية

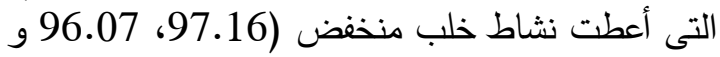

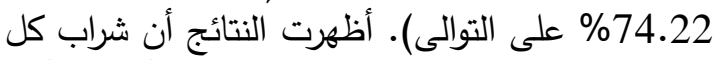
من الذرة الرفيعة السكرية و قصب السبا السكر أعطى تأثيرا

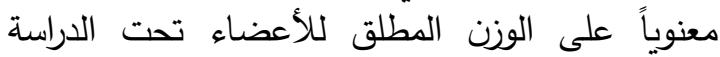

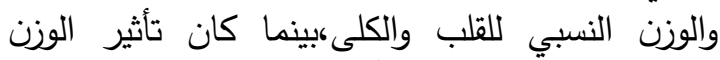

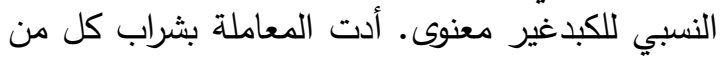

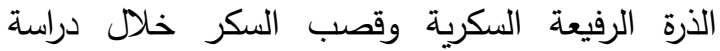
التأثير السام لخلات الكادميوم في الفئران إلى النيكن النفاض

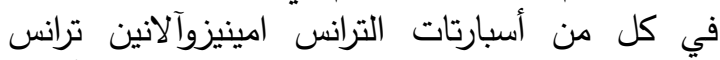
امينيز، اليوريا، الكرياتينين والإنزيمات المضات المبادة الأكسدة

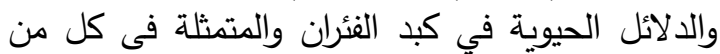

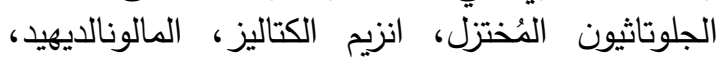

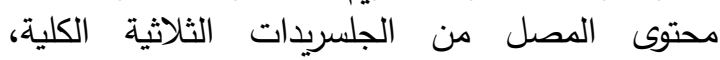
الكوليسترول الكلى، الكوليسترول مرتفع الكثاتية الكتاقة والكوليسترول منخفض الكثافة إلى مستويات قريبه من

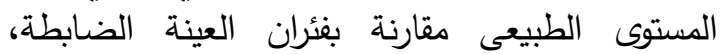
وخلصت الدراسة إلى أن المُعاملة بثران بشراب المحاصيل الماصيل

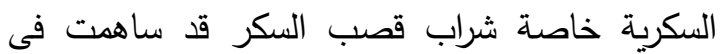
الإقلال من التأثير السام للكادميوم.

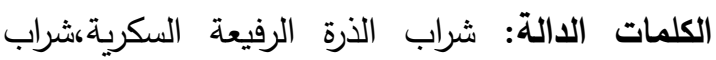
قصب السكر، الكادميوم، الإجهاد التأكسدي، الفئران

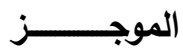

أجريت هذه الدراسة لمعرفة تأثير شراب كل من كن

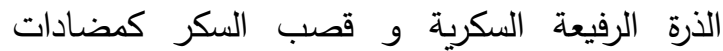

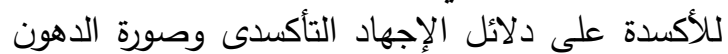

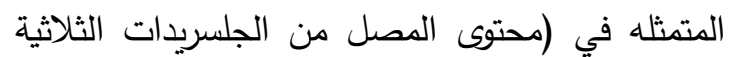
الكلية- الكوليسترول الكلى - الكولسترول مرتفع الكثافة

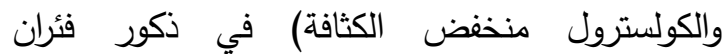

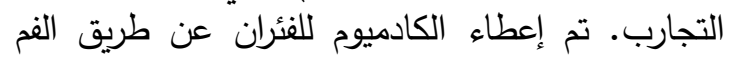

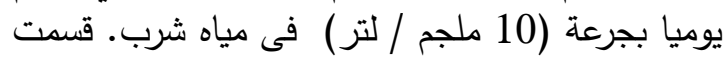
الفئران إلى أربعة مجموعات، ثماني فئران لكل منهاه لثربات (ا):

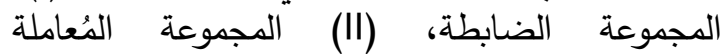
بالكادميوم، (III) المجموعة المُعاملة بكل من المكلة محلول شراب الذرة الرفيعة السكرية (500 جزء في المعادئ المليون)

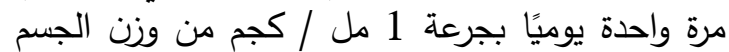

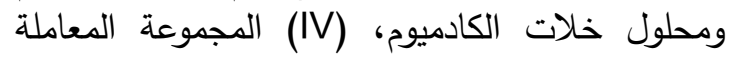
بمحلول قصب السكر (500 جزء في المليون) ومحلول خلات الكادميوم. تم تعريف المركبات الحيوية بعينات الماتيات الثراب تحت الدراسة بالإضافة إلى تقدير الثير المحتوى

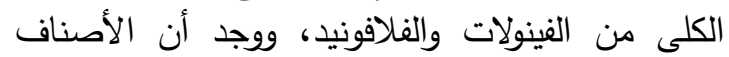

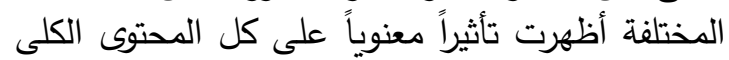

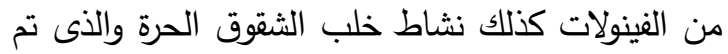
تقديره بواسطة الـ DPPH ، بينما كان تأثير الأصناف

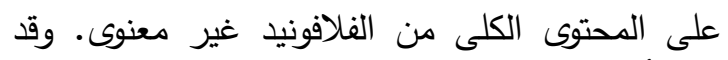

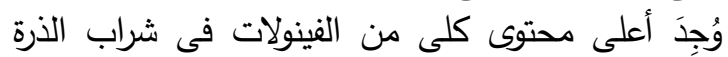

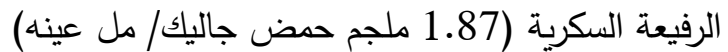
فى حين تراوحت النسبة الكلية من الفلافونيد بين 1.09

تحكيم: 1.د سامي محمد جلال

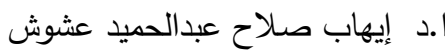


